\title{
Using Commercial Enzymes to Produce Cellulose Nanofibers from Soybean Straw
}

\author{
Milena Martelli-Tosi, ${ }^{1}$ Marcela da Silva Torricillas, ${ }^{1}$ Maria Alice Martins, ${ }^{2}$ \\ Odílio Benedito Garrido de Assis, ${ }^{2}$ and Delia Rita Tapia-Blácido ${ }^{1}$ \\ ${ }^{1}$ Departamento de Química, Faculdade de Filosofia, Ciências e Letras de Ribeirão Preto, Universidade de São Paulo, \\ Bandeirantes Avenue 3900, 14040-901 Ribeirão Preto, SP, Brazil \\ ${ }^{2}$ National Nanotechnology Laboratory for Agriculture, Embrapa Instrumentação, Rua XV de Novembro 1452, \\ 13561-206 São Carlos, SP, Brazil
}

Correspondence should be addressed to Delia Rita Tapia-Blácido; delia@ffclrp.usp.br

Received 26 May 2016; Revised 14 July 2016; Accepted 10 August 2016

Academic Editor: Zeeshan Khatri

Copyright (C) 2016 Milena Martelli-Tosi et al. This is an open access article distributed under the Creative Commons Attribution License, which permits unrestricted use, distribution, and reproduction in any medium, provided the original work is properly cited.

\begin{abstract}
This study used commercial enzymes to isolate cellulose nanofibrils $(\mathrm{CN})$ and produce sugars from chemically pretreated soybean straw (SS) (stem, leaves, and pods) by alkali $\left(\mathrm{NaOH} 5\right.$ or $17.5 \% \mathrm{v} / \mathrm{v}$ at $90^{\circ} \mathrm{C}$ for $1 \mathrm{~h}$ or at $30^{\circ} \mathrm{C}$ for $\left.15 \mathrm{~h}\right)$ and bleaching $\left(\mathrm{NaClO}_{2} 3.3 \%\right.$ or $\mathrm{H}_{2} \mathrm{O}_{2} 4 \%$ ) pretreatments. Depending on the pretreatment applied to the soybean straw, the yield of $\mathrm{CN}$ varied from 6.3 to $7.5 \mathrm{~g}$ of CN/100 g of SS regardless of the concentration of the alkaline solution (5 or 17.5\%). The CN had diameter of $15 \mathrm{~nm}$, measured over $300 \mathrm{~nm}$ in length, and had high electrical stability (zeta potentials ranged from -20.8 to -24.5 ). Given the XRD patterns, the crystallinity index (CrI) of $\mathrm{CN}$ ranged from 45 to $68 \%$, depending on the chemical pretreatment the starting material was submitted to. $\mathrm{CN}$ obtained from SS treated with $\mathrm{NaOH} 17.5 \%$ and $\mathrm{H}_{2} \mathrm{O}_{2}(\mathrm{CrI}=45 \%)$ displayed better thermal stability probably because a lignin-cellulose complex emerged. The soluble fraction obtained in the first step of $\mathrm{CN}$ production contained a large amount of reducing sugars (11.2 to $30.4 \mathrm{~g} / 100 \mathrm{~g}$ of SS). SS seems to be a new promising industrial source to produce CN via enzymaticmechanical treatment, leading to large amounts of reducing sugars for use in bioenergy production.
\end{abstract}

\section{Introduction}

Brazil is the second largest world producer of soybean, accounting for $30 \%$ of the global production. It comes after the United States, which accounts for about 35\% of the world production. According to Brazil's Ministry of Agriculture, Livestock, and Supply (MAPA), the country's soybean production reached 95 million tons (2014/2015 crop). Soybean harvesting residues generate stems, leaves, and pods, which are collectively designated soybean straw [1]. The straw is usually disposed as waste through landfilling, incineration, or dumping. The average composition of soybean straw is $35 \%$ cellulose, $21 \%$ insoluble lignin, $17 \%$ hemicelluloses, $11 \%$ ash, and $1 \%$ acid soluble lignin; the remaining constituents are protein, pectin, and glucuronic acid substitutes $[2,3]$. Stems and pods have slightly different lignocellulosic composition: the holocellulose content is $69.2 \%$ and $53.8 \%$, respectively, and the lignin content is $21.6 \%$ and $17.2 \%$, respectively [4]. Soybean stem displays lower ash contents than pods: $2.28 \%$ and $7.25 \%$, respectively. Therefore, soybean straw constitutes a source of lignocellulosic material, mainly cellulose fibers, and could be used to produce cellulose nanocrystal/nanofibers or in reducing sugars by chemical, physical, or enzymatic treatment.

As reviewed by Tang et al. [5], Abdul Khalil et al. [6], and Rhim et al. [7], the production of cellulose fibers with dimensions of about $10^{-9} \mathrm{~nm}$ has been widely pursued, and the resulting material has been applied in several areas, especially in nanocomposites. Normally, two main types of nanocellulose can be achieved: cellulose nanocrystals (CNC), obtained from treatment with concentrated acid, and cellulose nanofibers $(\mathrm{CN})$, arising from enzymatic and/or mechanical disintegration. $\mathrm{CNC}$ and $\mathrm{CN}$ differ in terms of their physical and chemical properties. Because $\mathrm{CN}$ form 
TABLE 1: Chemical pretreatments and lignocellulosic composition ( $\mathrm{g} / 100 \mathrm{~g}$ of d.b.) of the pretreated and untreated soybean straw (SS).

\begin{tabular}{lccccc}
\hline Sample & Treatment with alkali/bleaching & Cellulose & Hemicelluloses & Klason lignin & Acid soluble lignin \\
\hline SS untreated & - & $39.8 \pm 0.6$ & 22.6 & $10.5 \pm 0.7$ & $2.3 \pm 0.2$ \\
SS1 & $\mathrm{NaOH} 5 \%\left(1 \mathrm{~h} / 90^{\circ} \mathrm{C}-2 \mathrm{x}\right) / \mathrm{NaClO}_{2} 3.3 \%\left(3 \mathrm{~h} / 75^{\circ} \mathrm{C}\right)$ & $62.9 \pm 0.6$ & 11.1 & $4.9 \pm 0.2$ & $1.42 \pm 0.09$ \\
$\mathrm{SS} 2$ & $\mathrm{NaOH} 17.5 \%\left(1 \mathrm{~h} / 90^{\circ} \mathrm{C}-2 \mathrm{x}\right) / \mathrm{NaClO}_{2} 3.3 \%\left(3 \mathrm{~h} / 75^{\circ} \mathrm{C}\right)$ & $67.1 \pm 0.2$ & 9.8 & $4.1 \pm 0.2$ & $1.51 \pm 0.04$ \\
$\mathrm{SS} 3$ & $\mathrm{NaOH} 5 \%\left(15 \mathrm{~h} / 30^{\circ} \mathrm{C}\right) / \mathrm{H}_{2} \mathrm{O}_{2} 4 \%\left(3 \mathrm{~h} / 90^{\circ} \mathrm{C}\right)$ & $64.0 \pm 0.7$ & 10.7 & $3.6 \pm 0.1$ & $0.67 \pm 0.02$ \\
$\mathrm{SS} 4$ & $\mathrm{NaOH} 17.5 \%\left(15 \mathrm{~h} / 30^{\circ} \mathrm{C}\right) / \mathrm{H}_{2} \mathrm{O}_{2} 4 \%\left(3 \mathrm{~h} / 90^{\circ} \mathrm{C}\right)$ & $66.2 \pm 0.5$ & 9.5 & $3.5 \pm 0.1$ & $0.73 \pm 0.09$ \\
\hline
\end{tabular}

relatively large fiber agglomerates, they have larger aspect ratio and fiber entanglement but lower strain-at-failure [8].

$\mathrm{CN}$ morphology depends on the type of treatment the nanofibers are subjected to and on the source of lignocellulosic material. Several studies have produced and characterized nanocrystals from different bleached sources: pea hull fiber (diameter: 7-12 nm, length: 240-400 nm) [9], hemp and flax fibers (diameter: 20-40 nm, length: 100-500 nm) [10], cassava bagasse (diameter: 2-11 nm, length: $360-1700 \mathrm{~nm}$ ) [11], wheat straw and soy hulls (diameter: $30-40 \mathrm{~nm}$, length: $>100 \mathrm{~nm}$ ) [12, 13], sisal fibers (diameter: 2-11 nm, length: 360-1700 nm) [14], banana (pseudostem), jute (stem), and pineapple leaf fiber; mildly acid treatments have been used [15]. However, studies on CN from soybean straw have not been reported yet.

The literature on the use of enzymatic hydrolysis for $\mathrm{CN}$ production is scarce. Some authors have focused on the preparation of microfibrillated cellulose $[16,17]$. de Campos et al. [18] obtained CN from bleached curauá (diameter: 55$109 \mathrm{~nm}$, length: $1.3-4.1 \mu \mathrm{m}$ ) and sugarcane bagasse (diameter: 20-40 nm, length: $0.25-0.82 \mu \mathrm{m}$ ) by using enzymes (hemicellulase/pectinase and endoglucanase) and sonication. Tibolla et al. [19] produced similar CN from bleached banana peel bran by using xylanases (diameter: 7.6-10.9 nm, length: 0.5$2.9 \mu \mathrm{m}$ ). Recently, the use of cellulase before chemical treatments increased $\mathrm{CN}$ yield and improved $\mathrm{CN}$ properties [20].

The morphology of $\mathrm{CN}$ originating from enzymatic hydrolysis resembles the morphology of $\mathrm{CN}$ obtained by mechanical processes (high or ultrahigh-pressure homogenization), such as $\mathrm{CN}$ obtained from bleached sugar beet $\left(\mathrm{NaOH}\right.$ and $\mathrm{NaClO}_{2}$ ) (diameter: 30-100 nm, length: $>1 \mu \mathrm{m}$ ) $[21,22]$, bleached potato tuber cells (diameter: $2-4 \mathrm{~nm}$, length: $>1 \mu \mathrm{m}$ ) [23], and bleached softwood pulp with cellulose content above 95\% (diameter: 16-28 nm) [24]. Hydrothermal methods are alternative strategies to produce $\mathrm{CN}$ from mandarin peel waste [25]. Depending on the treatment and on the sequence of steps, microfibrillated cellulose will coexist with $\mathrm{CN}$ in the obtained suspensions.

All the methodologies used to produce nanocellulose involve treatment with alkali and bleaching steps that dissolve hemicelluloses and lignin from the lignocellulosic complex, to facilitate acid/enzymatic degradation. Pretreatments with alkali employ alkaline compounds such as potassium hydroxide $(\mathrm{KOH})$, sodium hydroxide $(\mathrm{NaOH})$, calcium hydroxide $\left(\mathrm{Ca}(\mathrm{OH})_{2}\right.$, also known as lime), or aqueous ammonia as catalyst to open up the biomass structure [26]. Treatments with alkali effectively dissolve hemicellulose, but other processes are necessary to hydrolyze lignin. Lignocellulose delignification via sodium chlorite $\left(\mathrm{NaClO}_{2}\right)$ bleaching has been traditionally used, but this process has been replaced with more environmentally friendly methods such as thermochemical reactions based on oxygen [27] and hydrogen peroxide $\left(\mathrm{H}_{2} \mathrm{O}_{2}\right)$ [28]. Therefore, new methodologies are welcome to obtain nanocellulose via more environmentally friendly processes, making the product a more attractive material for commercial applications.

This work aimed to produce and characterize CN from soybean straw by using commercial enzymes. Previous treatments with alkali ( $\mathrm{NaOH} 5 \%$ or $17.5 \%)$ and bleaching agents $\left(\mathrm{NaClO}_{2}\right.$ and $\left.\mathrm{H}_{2} \mathrm{O}_{2}\right)$ were conducted. Our goal was to compare a more environmentally friendly process that used $\mathrm{H}_{2} \mathrm{O}_{2}$ to the traditionally $\mathrm{NaClO}_{2}$ bleaching in order to obtain $\mathrm{CN}$ with acceptable properties and potential commercial applications.

\section{Materials and Methods}

2.1. Materials. Embrapa Soja (Londrina, Paraná, Brazil) supplied the soybean straw (SS). This raw material consists of around $27 \%$ stem, $41 \%$ leaves, and $32 \%$ pods (dry matter basis). SS was washed, dried at $50^{\circ} \mathrm{C}$, milled in a knife mill, and sieved through 35-mesh sieves (Tyler series, $500 \mu \mathrm{m}$ ). Chemical reagents such as $\mathrm{NaOH}, \mathrm{H}_{2} \mathrm{O}_{2}$, and $\mathrm{NaClO}_{2}$, which were used for the chemical pretreatment of SS, were of analytical grade.

2.2. Chemical Pretreatments. On the basis of the results obtained by de Campos et al. [18] and Andrade-Mahecha et al. [28], the SS underwent four different chemical pretreatments, with some modifications (Table 1). The SS was pretreated with $\mathrm{NaOH}$ solution 5 or $17.5 \mathrm{wt} \%$ under two conditions: $90^{\circ} \mathrm{C}$ for $1 \mathrm{~h}$, which was repeated twice, or $30^{\circ} \mathrm{C}$ for $15 \mathrm{~h}$. After that, the solution was brought to room temperature and rinsed to neutralization with the aid of a 400 Tyler mesh sieve. The fibers were then bleached by using two types of solution: a solution containing $0.7 \%$ acetic acid and $3.3 \% \mathrm{NaClO}_{2}$, agitated at $75^{\circ} \mathrm{C}$ for $4 \mathrm{~h}$; and another solution containing $\mathrm{H}_{2} \mathrm{O}_{2}, \mathrm{NaOH} 2 \%$, and $\mathrm{MgSO}_{4} \cdot 7 \mathrm{H}_{2} \mathrm{O} 0.3 \%$ (as stabilizer) at $90^{\circ} \mathrm{C}$ for $3 \mathrm{~h}$. The sample was cooled to room temperature. The fibers were filtered and washed with distilled water until neutral $\mathrm{pH}$ was reached, and then they were washed with ethanol and acetone. The fibers were dried in an oven with air circulation (Marconi, Brazil) at $50^{\circ} \mathrm{C}$.

2.3. Lignocellulosic Composition of SS. Untreated and treated SS were analyzed for their cellulose, holocellulose, and lignin content according to Sun et al. [29], TAPPI T19 om-54 [30], 


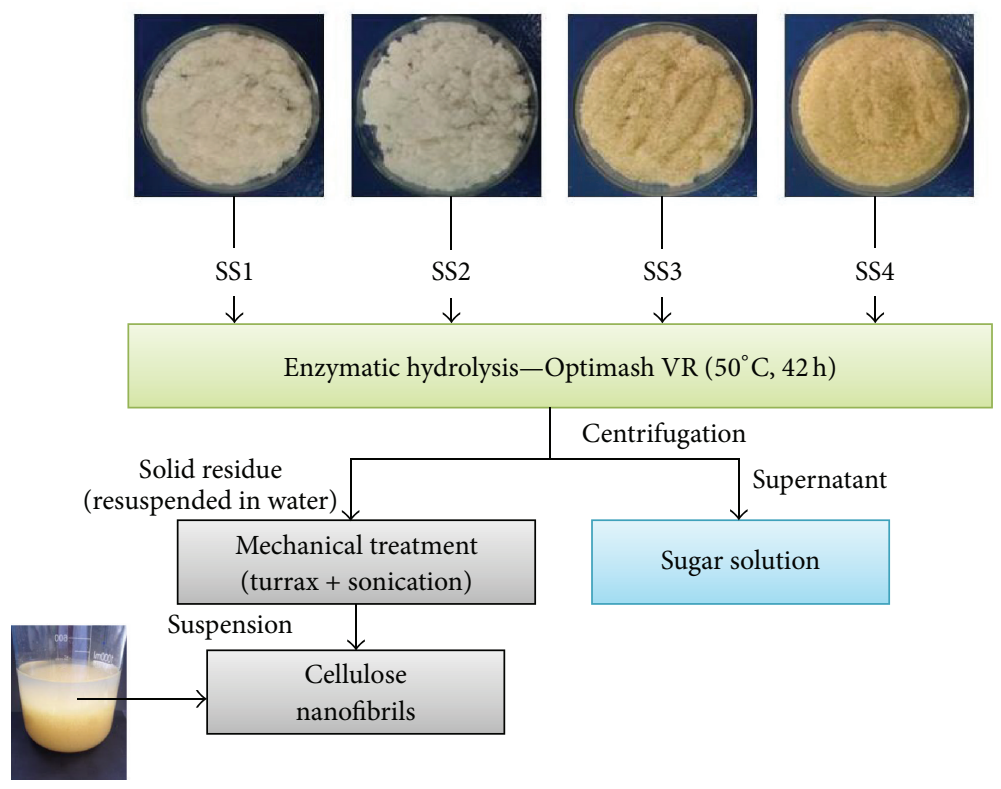

FIGURE 1: Enzymatic hydrolysis of chemically pretreated soybean straw (SS).

and TAPPI T 222 om-22 [31], respectively. Holocellulose corresponded to the fraction that contained cellulose and hemicelluloses.

2.4. Enzyme Activity Assays. DuPont (USA) supplied the enzymatic cocktail Optimash ${ }^{\mathrm{TM}}$ VR to prepare CN from SS. Before application of the enzymatic cocktail, enzyme activity assays were performed at Embrapa São Carlos according to the method described by Farinas et al. [32] and Florencio et al. [33]. A volume of the diluted enzymatic cocktail was incubated with the different substrates in $0.05 \mathrm{~mol} / \mathrm{L}$ acetate buffer, $\mathrm{pH} 4.0$, at $50^{\circ} \mathrm{C}$. The filter paper assay (FPase) and endoglucanase activity assay were accomplished according to Ghose methodology [34], by using $1 \times 6 \mathrm{~cm}$ Whatman number 1 filter paper and carboxymethylcellulose (CMC; Sigma, USA) as substrate, respectively. One unit (U) of enzyme activity corresponded to $1 \mathrm{mmol}$ of glucose released per minute at $\mathrm{pH} 4.0$ and $50^{\circ} \mathrm{C}$. The exoglucanase activity against insoluble substrate was determined by using $1 \%$ Avicel dissolved in $50 \mathrm{mM}$ citrate buffer, $\mathrm{pH} 4.0$, as substrate. The samples were incubated at $50^{\circ} \mathrm{C}$ for $120 \mathrm{~min}$ and agitated every $20 \mathrm{~min}$. Standard xylanase activity was measured according to Bailey et al. [35], by incubating a volume of diluted enzyme extract at $50^{\circ} \mathrm{C}$ for $30 \mathrm{~min}$ with $1 \%$ oat spelt xylan (Sigma, USA) solution prepared in $0.10 \mathrm{~mol} / \mathrm{L}$ sodium acetate buffer, $\mathrm{pH} 4.0$, as substrate. One $\mathrm{U}$ of xylanase activity corresponded to $1 \mathrm{mmol}$ of xylose released per minute at $\mathrm{pH} 4.0$ and $50^{\circ} \mathrm{C}$. The reducing groups released from both the assays were quantified according to the DNS method [36]. $\beta$-Glucosidase activity was determined by incubating an appropriate volume of the enzyme at $50^{\circ} \mathrm{C}$, for $30 \mathrm{~min}$, in $1 \mathrm{~mL}$ of $0.015 \mathrm{~mol} / \mathrm{L}$ cellobiose (Sigma, USA) solution prepared in $0.05 \mathrm{~mol} / \mathrm{L}$ sodium citrate buffer, $\mathrm{pH} 4.0$, used as substrate. The reaction was stopped by submersion in boiling water for $5 \mathrm{~min}$. The released glucose was determined by using an enzymatic kit to measure glucose.

2.5. Preparation of CN by Enzymatic Hydrolysis. The enzymatic hydrolysis experiments were carried out in $250 \mathrm{~mL}$ Erlenmeyer flasks containing $3 \mathrm{~g}$ of chemically treated SS (SS1, SS2, SS3, or SS4) and $150 \mathrm{~mL}$ of sodium acetate buffer at $\mathrm{pH}$ 4.0. The suspension was initially acclimatized at $50^{\circ} \mathrm{C}$ for $30 \mathrm{~min}$, under $200 \mathrm{rpm}$ agitation. Subsequently, $93 \mu \mathrm{L}$ of enzymatic cocktail Optimash VR/g of SS was added to the suspension at $50^{\circ} \mathrm{C}, \mathrm{pH} 4.0$, along the reaction period $(42 \mathrm{~h})$. The reaction was stopped by submersion of the Erlenmeyer flasks at $96^{\circ} \mathrm{C}$ for $15 \mathrm{~min}$, which was followed by centrifugation of the samples $\left(10,000 \mathrm{rpm}, 10^{\circ} \mathrm{C}, 10 \mathrm{~min}\right)$ (Continent R, Hanil, Republic of Korea). This step afforded two fractions, a soluble fraction rich in reducing sugars and an insoluble fraction (Figure 1). The reducing groups in the sugar solution (supernatant) were quantified according to the DNS method [36]. The insoluble fraction was resuspended in $150 \mathrm{~mL}$ of deionized water, and the suspension was homogenized on an ultraturrax disperser (T18 IKA, China) for $5 \mathrm{~min}$, which was followed by $3 \mathrm{~min}$ of probetype sonication (Branson 450, Switzerland). The suspension containing $\mathrm{CN}$ was separated, and $\mathrm{CN}$ morphology was characterized by Transmission Electron Microscopy (TEM), $\mathrm{X}$-Ray Diffraction (XRD), surface charge as determined by zeta potential, and thermogravimetric analysis (TGA). For the XRD and TGA analyses, $50 \mathrm{~g}$ of $\mathrm{CN}$ suspension was dried in a lyophilizer (Terroni, model LS3000, São Paulo, Brazil). Sodium azide $(0.1 \%, \mathrm{w} / \mathrm{v})$ was added in all the experiments to prevent fungal development during the hydrolysis step.

2.6. Yield of Nanofibers Production. The $\mathrm{CN}$ yield was determined by drying the $\mathrm{CN}$ suspension at $50^{\circ} \mathrm{C}$ until reaching 
constant mass $(\mathrm{CN})$ in an oven with air circulation (Marconi, Brazil). The $\mathrm{CN}$ yield ( $\mathrm{g} / 100 \mathrm{~g}$ of soybean straw) was calculated according to the following, where SS is the mass of soybean straw:

$$
\text { Yield of } \mathrm{CN}(\%)=\frac{\mathrm{CN}}{\mathrm{SS}} \times 100
$$

\subsection{Characterization of $C N$}

2.7.1. Zeta Potential. The zeta potential was measured on a Zetasizer Nano ZS instrument (Malvern Instruments, Ltd., UK) coupled to a ZEN 1020 dip cell. The mobility of tracer particles in the vicinity of the charged test surface fixed in the dip cell was measured by using phase analysis light scattering and a simple model that describes the electroosmotic flow near the surface. Three samples subjected to the same treatment and three measurements of each set of samples were examined to determine the zeta potential of the $\mathrm{CN}$ suspension. The measurements were repeated three times for each sample, at $25^{\circ} \mathrm{C}$.

2.7.2. Transmission Electron Microscopy (TEM). Transmission Electron Microscopy (TEM) helped us to observe the morphology and determine the diameter of the CN obtained from SS by enzymatic treatment. The $\mathrm{CN}$ suspension was placed in ultrasonic bath for $2 \mathrm{~min}$. Then, a drop of diluted suspension was deposited on a carbon-coated grid and dried at room temperature for $24 \mathrm{~h}$. The grid was stained with $1.5 \%$ uranyl acetate aqueous solution (immersion for $2 \mathrm{~min}$ ) and dried at room temperature. Microscopic analyses were performed on a JOEL electron microscope (JEM 100CXII, Tokyo, Japan) operating at $80 \mathrm{kV}$. The $\mathrm{CN}$ diameters and length were determined with the aid of image processing analysis software (Image J), by using TEM images. Around 30 measurements were performed for each sample.

2.7.3. CN Crystallinity by X-Ray Diffraction (XRD). The XRD patterns of $\mathrm{CN}$ powder were recorded on an X-ray diffractometer (Lab XXDR-6000, Shimadzu, Tokyo, Japan) operating with CuKa radiation (wavelength $=1.5406 \AA$ ) at $30 \mathrm{kV}$ and $30 \mathrm{~mA}$. The measurements were carried out from $2 \theta=5^{\circ}$ to $2 \theta$ $=40^{\circ}$, at a scan rate of $1^{\circ} \mathrm{min}^{-1}$. The crystallinity index (CrI) of the material was determined by using the Segal method [37] as follows:

$$
\mathrm{CrI}=\frac{\left(I_{002}-I_{\mathrm{am}}\right)}{I_{002}} * 100
$$

where CrI expresses the relative degree of crystallinity, $I_{002}$ is the intensity of the 002 lattice diffraction at $2 \theta=22.8^{\circ}$, and $I_{\text {am }}$ is the intensity of the diffraction at $2 \theta=18^{\circ} . I_{002}$ represents the crystalline contribution, while $I_{\mathrm{am}}$ represents the amorphous diffraction.

2.7.4. Thermal Characterization. The thermal stability of $\mathrm{CN}$ was evaluated on a Thermogravimetric Analyzer TGA-Q500 (TA Instruments, New Castle, DE, USA). Approximately $10 \mathrm{mg}$ of each sample was weighed and sealed in platinum
TABLE 2: Optimash VR enzymatic activities for endoglucanase, xylanase, $\beta$-glucosidase, exoglycosidase, and filter paper (conditions: $50^{\circ} \mathrm{C}$ and $\mathrm{pH} 4.0$ ).

\begin{tabular}{lc}
\hline Enzyme activities & $\begin{array}{c}\text { Optimash VR activities } \\
(\mathrm{U} / \mathrm{mL} \text { of enzymatic cocktail) }\end{array}$ \\
\hline Endoglucanase & $1441 \pm 32$ \\
Xylanase & $4796 \pm 103$ \\
$\beta$-Glucosidase & $135 \pm 7$ \\
Exoglucanase & $101 \pm 12$ \\
FPase & $17.1 \pm 0.9$ \\
\hline
\end{tabular}

pans. The analyzed temperatures ranged from 20 to $700^{\circ} \mathrm{C}$; the heating rate was $10^{\circ} \mathrm{C}$ per minute. The analyses were conducted in nitrogen atmosphere.

2.8. Statistical Analyses. Analysis of variance (ANOVA) and Tukey's test $(p<0.05)$ were applied at a 5\% significance level to compare means for yield, zeta potential, and dimensions of $\mathrm{CN}$ as well as for concentration of reducing sugars obtained by enzymatic hydrolysis from chemically pretreated soybean straw (SS1, SS2, SS3, and SS4). Statistical analysis was performed using Statistica 12 software $\left(\right.$ StatSoft $\left.{ }^{\circledR}\right)$.

\section{Results and Discussion}

3.1. Lignocellulosic Composition. Table 1 shows the lignocellulosic composition of untreated and chemically treated SS. After the chemical treatments (treatment with alkali and bleaching), the cellulose content increased from 39.8 to $67.1 \%$ of soybean, whereas the hemicellulose and lignin contents decreased from 22.6 to $9.5 \%$ and from 12.8 to $4.2 \%$, respectively, as compared to the untreated fiber. As expected, treatment of lignocellulosic fibers with alkali solubilized lignin and the remaining pectins and hemicelluloses and increased the surface area of the fibers, affording polysaccharides that were more susceptible to hydrolysis [12, 23]. Increased cellulose content was more pronounced when chemical treatment with $\mathrm{NaOH} 17.5 \%$ (SS2) was applied.

3.2. Activities of Enzymatic Cocktail. Table 2 lists the Optimash VR enzymatic cocktail activities. Xylanases (4796 U/ $\mathrm{mL}$ ) and endoglucanases (1441 CMC U/mL) accounted for the enzymatic activity, followed by exoglucanases $(101 \mathrm{U} / \mathrm{mL})$ and $\beta$-glucosidases $(135 \mathrm{U} / \mathrm{mL})$. When filter paper was used as substrate, the enzymatic activity was only $17.1 \mathrm{U} / \mathrm{mL}$, mainly due to the complex structure of the substrate. Based on preliminary studies, we used $93 \mu \mathrm{L}$ of enzymatic cocktail for each $\mathrm{g}$ of SS, which corresponded to $134 \mathrm{CMC} \mathrm{U}$ and 446 xylanase $U$ for each $g$ of SS. Xylanase efficiently removed hemicellulose and lignin fractions from the treated fibers (SS1, SS2, SS3, and SS4). In addition, xylanase attacked the amorphous regions and helped to cleave the $\beta-1.4$ glycosidic bonds, isolating the CN [19].

3.3. Enzymatic Hydrolysis: $C N$ Yield and Zeta Potential. In preliminary study on kinetics of sugar production (results not 
TABLE 3: CN production yield (\%) (g of nanofiber/100 $\mathrm{g}$ of SS) and zeta potential $(\mathrm{mV})$ of the $\mathrm{CN}$ suspension obtained by enzymatic hydrolysis of chemically pretreated soybean straw (SS1, SS2, SS3, and SS4).

\begin{tabular}{lcc}
\hline $\begin{array}{l}\text { CN } \\
\text { suspension }\end{array}$ & $\begin{array}{c}\text { CN yield } \\
\text { (g of nanofibers/100 g of SS) }\end{array}$ & $\begin{array}{c}\text { Zeta potential } \\
(\mathrm{mV})\end{array}$ \\
\hline SS1 & $7.4 \pm 1.3^{\mathrm{a}}$ & $-21.7 \pm 4.3^{\mathrm{a}}$ \\
SS2 & $6.6 \pm 2.2^{\mathrm{a}}$ & $-20.8 \pm 3.9^{\mathrm{a}}$ \\
SS3 & $7.5 \pm 1.1^{\mathrm{a}}$ & $-22.5 \pm 4.2^{\mathrm{a}}$ \\
SS4 & $6.3 \pm 0.6^{\mathrm{a}}$ & $-24.5 \pm 4.4^{\mathrm{a}}$ \\
\hline
\end{tabular}

Values are expressed as mean \pm standard deviation. Letters "a" in the same column indicate no significant differences among the samples.

shown) by enzymatic hydrolysis of SS, we found that $42 \mathrm{~h}$ was the time that provided the best $\mathrm{CN}$ yield. Table 3 presents the $\mathrm{CN}$ production yield and the zeta potential of the $\mathrm{CN}$ suspension. Enzymatic treatment yielded between 6.3 and $7.5 \mathrm{~g}$ of CN/100 $\mathrm{g}$ of SS. Preliminary tests showed that high enzyme concentration did not improve the $\mathrm{CN}$ yield (results not shown). Treatment of SS with alkali increased the CN yield slightly. Interestingly, the starting SS treated with $\mathrm{NaOH}$ 5\% (SS1 and SS3) presented higher CN yield (7.4 and $7.5 \mathrm{~g}$ of CN/100 g of SS, resp., corresponding to 0.11 and $0.18 \mathrm{~g}$ of $\mathrm{CN} / \mathrm{g}$ of $\mathrm{CN}$ suspension, resp.) as compared to the starting SS treated with $\mathrm{NaOH} 17.5 \%$ (6.6 and $6.3 \mathrm{~g}$ of $\mathrm{CN} / 100 \mathrm{~g}$ of SS for SS3 and SS4, resp.). The CN concentration in the suspensions was much higher than the $\mathrm{CN}$ concentration obtained by acid treatment $\left(\mathrm{H}_{2} \mathrm{SO}_{4} 1 \%, 80^{\circ} \mathrm{C}, 1 \mathrm{~h}\right)$ or enzymatic hydrolysis of bleached peel of unripe plantain banana: 0.0054 and $0.0057 \mathrm{~g} / \mathrm{g}$ of suspension, respectively [19].

Mechanical processes normally give $\mathrm{CN}$ yields lower than 5\%, as described by Filson and Dawson-Andoh [38], who isolated nanofiber from recycled pulp and Avicel. On the other hand, acid hydrolysis of isora fibers can increase the production of nanocrystals, yielding up to $48 \%$ [39] or $71.3 \%$ [20]. Depending on the lignocellulosic source, even severe acid treatments $\left(\mathrm{H}_{2} \mathrm{SO}_{4} 64 \%\right)$ cannot generate high amounts of $\mathrm{CN}$; for example, bleached soybean hulls treated with acid afforded only $8-20 \%$ of CN yield [40].

The performance of nanofibers as reinforcing agent is also associated with the surface charge or zeta potential. The zeta potential indicates how stable colloidal dispersions are. Nanofibers should have high zeta potential to prevent aggregation and increase their degree of dispersion in the biocomposite. In the present study, $\mathrm{CN}$ suspensions exhibited negative zeta potential ranging from -20.8 to $-24.5 \mathrm{mV}$. No significant differences $(p>0.05)$ were observed between the zeta potential values of the different starting materials (SS1, SS2, SS3, or SS4). The magnitude of the zeta potential indicates the degree of electrostatic repulsion between adjacent, similarly charged particles in a dispersion. Colloidal suspensions with zeta potential values between \pm 10 and \pm 30 and between \pm 30 and \pm 40 display incipient instability and moderate stability, respectively. In fact, the stability behavior (electrokinetic potentials) of colloidal suspensions is closely related to the driving force (pressure drop that makes the
TABLE 4: Dimensions of CN obtained by enzymatic hydrolysis of chemically pretreated soybean straw (SS1, SS2, SS3, and SS4).

\begin{tabular}{lccc}
\hline $\begin{array}{l}\text { CN } \\
\text { suspension }\end{array}$ & Diameter $(\mathrm{nm})$ & Length $(\mathrm{nm})$ & $\begin{array}{c}\text { Aspect ratio } \\
(L / D)\end{array}$ \\
\hline SS1 & $7.6 \pm 3.4^{\mathrm{b}}$ & $216 \pm 122^{\mathrm{a}, \mathrm{c}}$ & $33 \pm 26^{\mathrm{a}}$ \\
SS2 & $11.5 \pm 4.2^{\mathrm{a}}$ & $131 \pm 89^{\mathrm{b}}$ & $13 \pm 10^{\mathrm{b}}$ \\
SS3 & $9.2 \pm 2.6^{\mathrm{b}}$ & $237 \pm 101^{\mathrm{a}}$ & $26 \pm 11^{\mathrm{ab}}$ \\
SS4 & $9.3 \pm 2.9^{\mathrm{b}}$ & $159 \pm 86^{\mathrm{b}, \mathrm{c}}$ & $19 \pm 12^{\mathrm{b}}$ \\
\hline
\end{tabular}

Values are expressed as mean \pm standard deviation. Different letters, $a, b$, and $c$, in the same column indicate significant differences $(p<0.05)$ among the samples.

solution flow), the surface property of the material, and the solution properties (ionic strength, $\mathrm{pH}$ ) [41].

The zeta potential values of $\mathrm{CN}$ obtained in this work were higher than the zeta potential values obtained by Satyamurthy et al. [17] for $\mathrm{CN}$ prepared from cotton by microbial hydrolysis $(-14.6 \mathrm{mV})$. Nanocrystals prepared by acid hydrolysis normally bear higher negative charge on the surface of the nanoparticles, for example, $-69.5 \mathrm{mV}$ [42] and $-124 \mathrm{mV}$ [20]. Smaller length and attachment of sulfate groups to the nanoparticle surface account for this difference. Although severe acid treatments generate more stable nanofibers, this treatment lacks ecofriendliness.

The use of cellulases before acid treatments reveals the buffer exerts a negative effect on the nanocrystal stability (the zeta potential decreases from -124 to $-53 \mathrm{mV}$ ) [20]. This could be due to either modification of the ionic distribution around cellulose fibers prompted by ions provided by the buffer [20] or influence of the $\mathrm{pH}$.

3.4. Transmission Electron Microscopy (TEM). Figure 2 illustrates the TEM micrographs of the $\mathrm{CN}$ obtained after enzymatic treatment of the pretreated soybean straw (SS1, SS2, SS3, and SS4). The micrographs clearly supported isolation of $\mathrm{CN}$ from chemically pretreated SS. CN produced from SS1, SS3, and SS4 had similar morphology. In general, CN comprised a network of long entangled cellulosic filaments with diameter of $9.4 \mathrm{~nm}$ on average and lengths above $100 \mathrm{~nm}$ (see Table 4). The more severe chemical pretreatment (SS2) significantly affected $\mathrm{CN}$ morphology. The $\mathrm{CN}$ obtained from SS2 had a more gelatinous aspect, contained some spherical structures, and displayed larger particle diameters $(11.5 \mathrm{~nm}$ as compared to 7.5 to $9.3 \mathrm{~nm}$ measured for the $\mathrm{CN}$ obtained from SS1, SS3, and SS4). The CN obtained from SS2 were probably more swollen, so the $\mathrm{CN}$ became thicker during the drying process conducted previously to TEM analysis. In contrast, the average lengths of SS2-CN $(131 \mathrm{~nm})$ and SS4CN $(159 \mathrm{~nm})$ were smaller as compared to SS1-CN (216 nm) and SS3-CN $(237 \mathrm{~nm})$. The more severe treatment with alkali (NaOH $17.5 \%)$ applied to SS2 and SS4 probably facilitated enzymatic action on the amorphous region, so that lignin and hemicelluloses were more easily removed from the internal structure of the cellulose in this region. As a result, the SS2-CN and SS4-CN samples contained smaller CN, and their aspect ratios (length/diameter) were twice as lower as the aspect ratio of SS1-CN and SS3-CN. The length of 


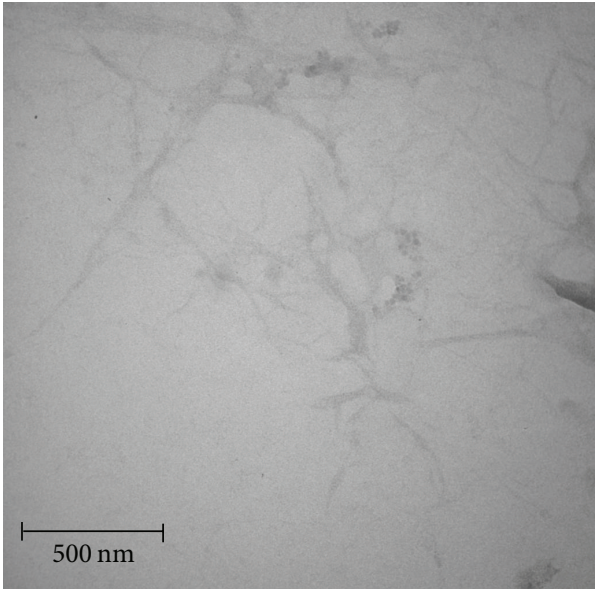

(a) SR1-CN

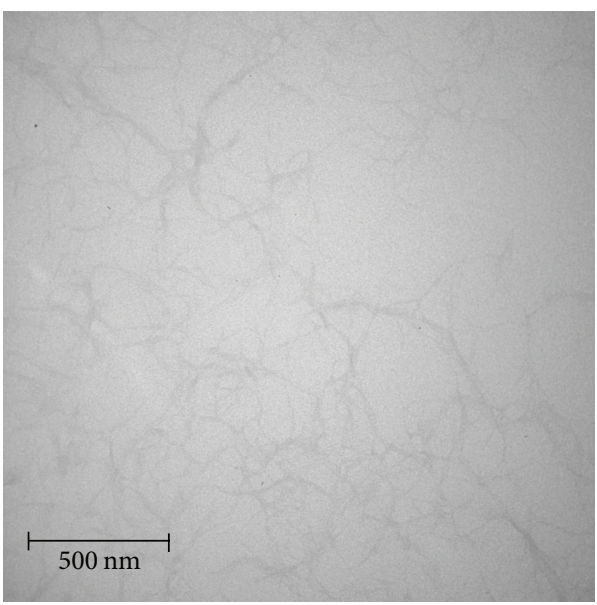

(c) SR3-CN

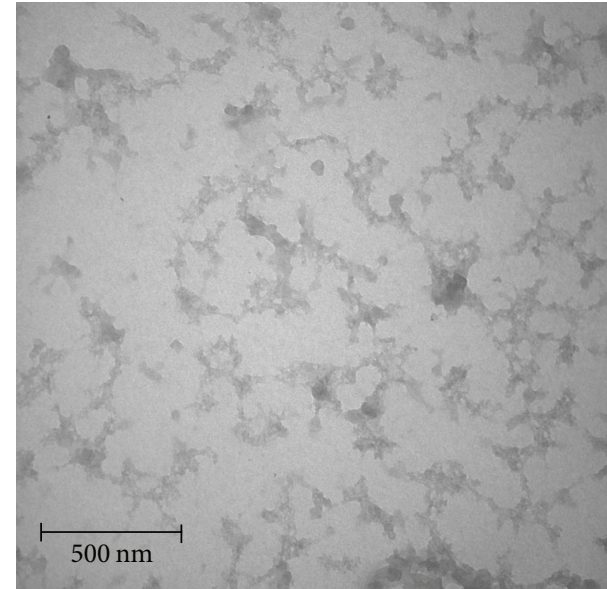

(b) SR2-CN

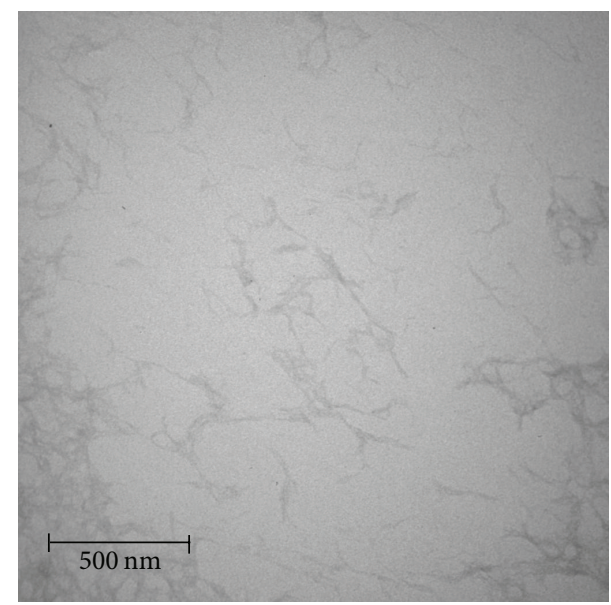

(d) SR4-CN

FIGURE 2: TEM micrographs of cellulose nanofibers (CN) obtained by enzymatic hydrolysis of chemically pretreated soybean straw: SS1, SS2, SS3, and SS4. 1, 2, 3, and 4 stand for the different SS submitted to the chemical treatments described in Table 1.

the nanocrystals obtained from soybean hulls was slightly smaller $(103-123 \mathrm{~nm})$, and the aspect ratio was around 26 [40] or about 15-40 [12]. The lower values obtained by acid hydrolysis were mainly due to the smaller length, given that the nanofiber diameter fell in the same range as the nanofiber diameter obtained by enzymatic/mechanical treatments.

The aspect ratio plays a major role in determining the reinforcing capacity of nanofibers because it affects the ability of the fiber to maintain the film network. Most of the nanofibers obtained from enzymatic and/or mechanical treatments display different aspect ratio depending on the starting material and treatment, namely, aspect ratio in the range of 120-150 for nanofibers obtained from areca nut (alkali: $\mathrm{NaOH} 5 \%$, acid: $\mathrm{HCl}$, bleaching: $\mathrm{NaClO}_{2}$, and homogenization: Ultraturrax 12000) [43] and aspect ratio in the range of 23-38 for nanofibers obtained from curauá [20]. Thus, mechanical treatment underlies $\mathrm{CN}$ formation.

3.5. Nanofiber Crystallinity. Figure 3 represents the XRD patterns of the $\mathrm{CN}$ obtained from chemically pretreated SS by enzymatic hydrolysis. The patterns were typical of semicrystalline cellulosic materials with an amorphous broad band and defined crystalline peaks. The main differences in the crystallinity peaks of SS1-CN, SS2-CN, SS3-CN, and SS4-CN were due to chemical pretreatment type used $(\mathrm{NaOH} 5$ or $17.5 \%, \mathrm{NaClO}_{2}$, and $\mathrm{H}_{2} \mathrm{O}_{2}$ ) and not to enzymatic activity. During the enzymatic hydrolysis, the enzymes cleaved the glycosidic chains in cellulose, diminishing fiber size without modifying the crystalline structure of the polysaccharide. The amorphous bands were more evident in the XRD of the samples SS3-CN and SS4-CN. $\mathrm{H}_{2} \mathrm{O}_{2}$ was the bleaching agent in these cases. Bearing in mind that sugars are amorphous, the fact that some sugar released by the enzymes remained in the $\mathrm{CN}$ suspension could influence the crystalline signals of nanocellulose.

Type I cellulose predominated in all the diffractogram profiles, as verified by the presence of identifiable peaks at $2 \theta=17^{\circ}$ (plane 101), $23^{\circ}$ (plane 002), and $34^{\circ}$ (plane 004). A mixture of polymorphs of cellulose I and cellulose II emerged for the CN prepared from SS treated with higher contents of 


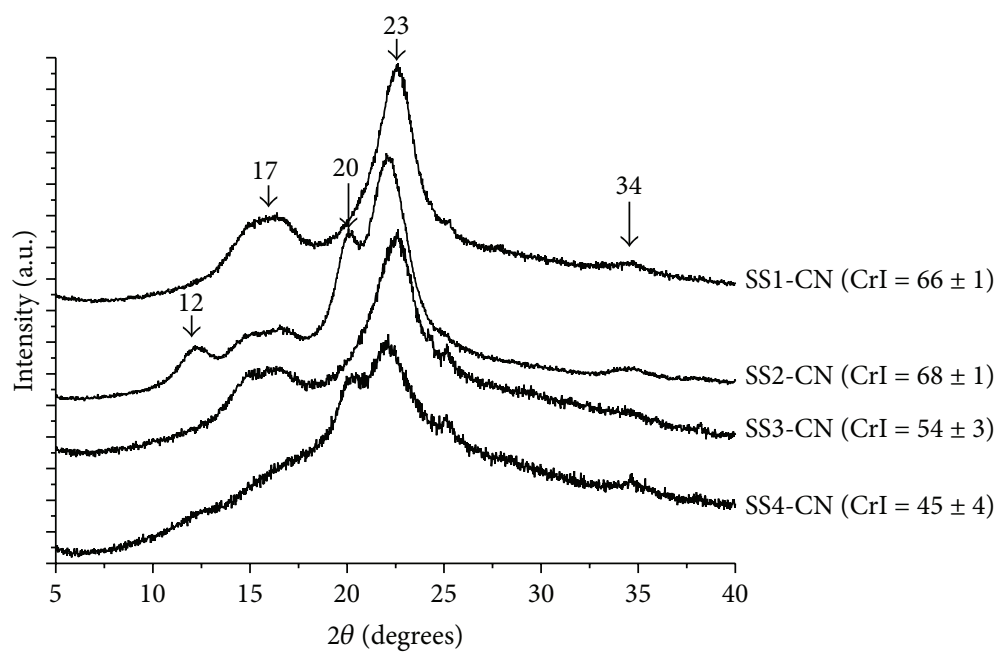

FIGURE 3: XRD pattern and crystalline index (CrI) of cellulose nanofibers (CN) obtained by enzymatic hydrolysis of chemically pretreated soybean straw: SS1, SS2, SS3, and SS4. 1, 2, 3, and 4 stand for the different SS submitted to the chemical treatments described in Table 1.

alkali ( $\mathrm{NaOH} 17.5 \%, \mathrm{SS} 2$ and SS4). The peaks at $2 \theta=12^{\circ}$ (plane $101), 20^{\circ}$ (plane 101 ), and $22^{\circ}$ (plane 002) $[44,45]$ characterized the presence of cellulose type II. The main difference between cellulose allomorphs lies in the structure of the unit cell (dimensions, parallel/antiparallel glucan chains). Cellulose II normally results from severe treatments with alkali [40, 44, 45 ] or is also associated with cellulose reprecipitation after hydrolysis in the presence of strong sulfuric acid solution $[40,46]$.

The resulting crystallinity indexes $(\mathrm{CrI})$ of $\mathrm{CN}$ are presented in Figure 3. CN crystallinity varied depending on the pretreated SS. SS1-CN and SS2-CN presented CrI of around 67\%, whereas SS3-CN and SS4-CN afforded lower indexes (54\% and $45 \%$, resp.). The main difference between SS1/SS2 and SS3/SS4 was the bleaching step. In the first case, $\mathrm{NaClO}_{2}$ was the main delignifying agent, whereas in the second case $\mathrm{H}_{2} \mathrm{O}_{2}$ was used instead of $\mathrm{NaClO}_{2}$. Both treatments effectively dissolved lignin, as can be observed in Table 1 . The results suggested that $\mathrm{H}_{2} \mathrm{O}_{2}$-based treatments not only removed the amorphous portion of cellulose but also degraded the crystalline ones, resulting in lower CrI. SS2-CN also had smaller length than the other $\mathrm{CN}$, so in this case enzymatic hydrolysis disrupted the amorphous region more effectively, to produce some nanocrystals.

3.6. Cellulose Nanofiber Thermal Stability. Thermal decomposition parameters were determined from the TG and DTG curves presented in Figures 4(a) and 4(b), respectively. The chemical pretreatment of soybean straw influenced the thermal degradation of the $\mathrm{CN}$ obtained by enzymatic hydrolysis, mainly after $350^{\circ} \mathrm{C}$. In TG curve, it can be observed that the first decomposition stage occurred between 50 and $100^{\circ} \mathrm{C}$ and corresponded to loss of 5-9\% of mass due to desorption of physically and chemically bound water. In the second event, between 150 and $250^{\circ} \mathrm{C}, 6.0$ to $9.0 \%$ of matter was degraded, which could be due to degradation of low-molecular-weight compounds remaining from the isolation procedures. At this point, SS2-CN and SS4-CN presented larger weight losses probably because the sugar released by the enzymes remained in the $\mathrm{CN}$ suspension. Once again, the enzymes removed sugars from samples chemically treated with $\mathrm{NaOH} 17.5 \%$ (SS2 and SS4) more effectively. The third stage referred to degradation of lignocellulosic compounds, and the samples presented different thermal degradability during this step. According to Yang et al. [47], hemicellulose starts to decompose at $220^{\circ} \mathrm{C}$, which continues up to $300^{\circ} \mathrm{C}$, with maximum decomposition at $268^{\circ} \mathrm{C}$. Cellulose decomposition begins at $310^{\circ} \mathrm{C}$ and persists until $400^{\circ} \mathrm{C}$, whereas lignin decomposition extends to the whole temperature range, starting well below $200^{\circ} \mathrm{C}$ and persisting above $700^{\circ} \mathrm{C}$. Solid residues correspond to $20 \mathrm{wt} . \%$ at $700^{\circ} \mathrm{C}$. In the present study, the samples differed with respect to the decomposition peak and mass loss at this stage. SS4-CN decomposition peaked at the highest temperature, $343^{\circ} \mathrm{C}$, which corresponded to $56.3 \%$ mass loss. The decomposition peak of the other samples emerged between 318 and $327^{\circ} \mathrm{C}$ (SS1-CN and SS3-CN, resp.), and mass loss was $60.1,57.3$, and $61.4 \%$ for SS1-CN, SS2-CN, and SS3-CN, respectively. Therefore, CN extracted from SS4 had the highest thermal stability among the prepared samples. Its stability resembled the thermal stability of nanocellulose obtained from banana fiber, which decomposed at $346^{\circ} \mathrm{C}$ [15], and was higher than the thermal stability of most nanocelluloses studied to date, which normally ranges from 310 to $326^{\circ} \mathrm{C}[24]$.

Finally, the last event took place between 380 and $500^{\circ} \mathrm{C}$ and corresponded mainly to lignin degradation (the most stable of the three compounds). In this stage, SS1-CN, SS2$\mathrm{CN}$, and SS3-CN lost about $20 \%$ of their mass, and their residual mass was close to $4 \%$. However, SS4-CN lost only $7.1 \%$ of its mass, and its residual mass was $10 \%$. As mentioned by Abraham et al. [15], the thermal stability of lignin changes depending on the chemical bonds present in its structure. Lignin-cellulose complex may be formed during the production of nanocellulose by the interaction of the 


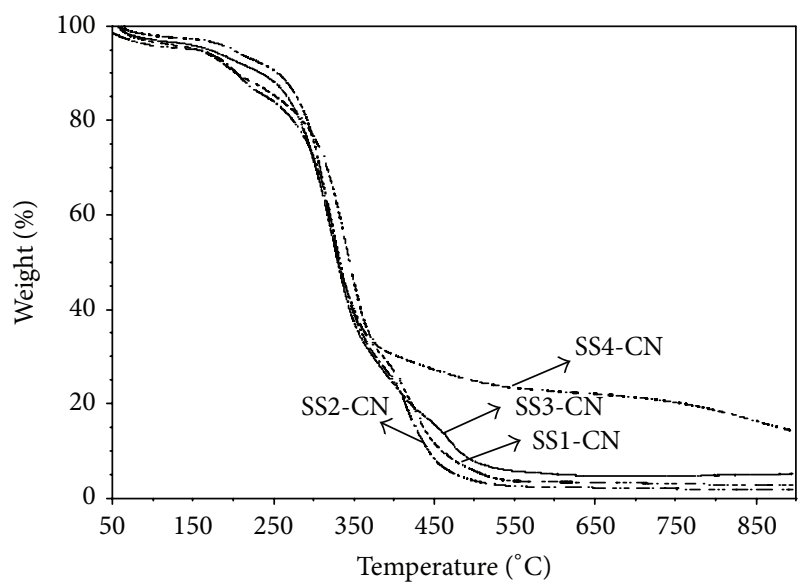

(a)

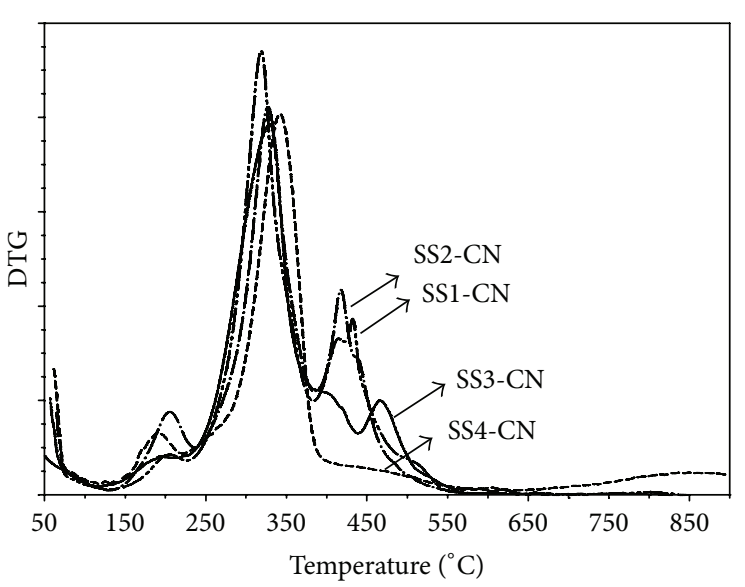

(b)

FIGURE 4: TG (a) and DTG (b) curves for cellulose nanofibers (CN) obtained by enzymatic hydrolysis of the chemically pretreated soybean straw: SS1, SS2, SS3, and SS4. 1, 2, 3, and 4 stand for the different SS submitted to the chemical treatments described in Table 1.

TABLE 5: Concentration of reducing sugars ( $\mathrm{g} / 100 \mathrm{~g}$ of SS) in the solution obtained after enzymatic hydrolysis of soybean residue using the commercial enzymatic cocktail Optimash VR (DuPont, USA) for $42 \mathrm{~h}\left(\mathrm{pH}=4.0\right.$ and $\left.\mathrm{T}=50^{\circ} \mathrm{C}\right)$.

\begin{tabular}{lc}
\hline $\begin{array}{l}\text { Sugar solution from CN } \\
\text { production }\end{array}$ & $\begin{array}{c}\text { Reducing sugars (\%) } \\
\text { (g of glucose/100 g of SS) }\end{array}$ \\
\hline SS1 & $13.3 \pm 1.0^{\mathrm{b}}$ \\
SS2 & $29.0 \pm 0.9^{\mathrm{a}}$ \\
SS3 & $11.2 \pm 0.6^{\mathrm{b}}$ \\
SS4 & $30.4 \pm 1.1^{\mathrm{a}}$ \\
\hline
\end{tabular}

Values are expressed as mean \pm standard deviation. Different letters, a and $\mathrm{b}$, in the same column indicate significant differences $(p<0.05)$ among the samples.

remaining lignin and cellulose. Therefore, lignin may protect the cellulose during the thermal degradation increasing the cellulose degradation temperature and the residual mass.

\subsection{Production of Reducing Sugars during Enzymatic Hydroly-} sis. The methodology proposed herein to produce $\mathrm{CN}$ from SS (Figure 1) afforded a soluble fraction that was separated by centrifugation after enzymatic hydrolysis (supernatant). This fraction was rich in reducing sugars (Table 5). SS2 and SS4 enzymatic hydrolysis provided higher concentration of sugars (29.0-30.4\%) as compared to SS1 (13.3\%) and SS3 $(11.2 \%)$. This result was a consequence of the effect of the concentration of alkali and not of the type of bleaching agent on the activities of the enzymes. Considering that the starting material had similar composition (Table 1), $\mathrm{NaOH}$ at higher concentration (17.5\%) gave a different cellulose structure, as evidenced by the XRD patterns (Figure 3 ). The presence of cellulose type II in SS2 and SS4 made cellulose easily accessible to the enzymes of the cocktail. In brief, xylanases act on the glycoside linkages of xylan, hydrolyzing part of hemicelluloses [48]. On the other hand, cellulases can access the amorphous region of cellulose by action of endoglucanases or the extremity of the chain by action of exoglucanases [49]. These enzymes fragment the $\beta-1,4$ bonds into smaller chains. Cellobiohydrolases rapidly hydrolyze the oligomers to the elementary unit of cellulose. Cellobiose (glucose dimer) and glucosidases can produce glucose units [50].

\section{Conclusions}

Production of cellulose nanofibrils from soybean straw by enzymatic-mechanical treatments also affords a coproduct (a solution) with up to $30.4 \%$ of reducing sugars, which can have further biotechnological applications such as generation of bioethanol or biogas. Effective extraction of cellulose nanofibrils requires previous mercerization of the fiber to dissolve the noncrystalline particles of the lignocellulosic fibers. Chemical pretreatment with alkali and bleaching agents $\left(\mathrm{NaClO}_{2}\right.$ and $\left.\mathrm{H}_{2} \mathrm{O}_{2}\right)$ effectively removes $51-59 \%$ of hemicellulose and up to $68 \%$ of lignin contents, providing a material rich in cellulose (63-67\%). Alkali at higher concentration $(17.5 \%)$ leads to more effective hydrolysis of the lignocellulosic complex by the enzymes. Indeed, cellulose nanofibers obtained from the starting materials SS2 $\mathrm{NaOH}$ $\left.17.5 \%, \mathrm{NaClO}_{2}\right)$ and SS4 $\left(\mathrm{NaOH} 17.5 \%, \mathrm{H}_{2} \mathrm{O}_{2}\right)$ present smaller length and high contents of sugars in the supernatant than those obtained from SS pretreated with $\mathrm{NaOH}$ 5\% (SS1 and SS3). In the particular case of the sample treated with $\mathrm{NaOH}$ $17.5 \%$ and $\mathrm{H}_{2} \mathrm{O}_{2}$, the nanofibers present higher thermal stability, suggesting that a lignin-cellulose complex may have emerged. The enzymatic-mechanical treatment yields cellulose nanofibers with diameters of 5-15 nm, constituting a potential methodology to isolate these nanofibers from different bleached soybean straw. Therefore, $\mathrm{H}_{2} \mathrm{O}_{2}$ can be successfully used as bleaching agent in treatments conducted prior to cellulose nanofibrils production via enzymatic hydrolysis, being more ecological than pretreatments that employ $\mathrm{NaClO}_{2}$. 


\section{Competing Interests}

The authors declare that there is no conflict of interests regarding the publication of this manuscript.

\section{Acknowledgments}

The authors gratefully acknowledge the funding agency FAPESP (São Paulo, Brazil) for financial support of article processing charges (2016/16222-0), for the postdoctoral fellowship granted to Milena Martelli-Tosi (2012/22154-7) and the IC fellowships granted to Marcela da Silva Torricillas (2014/02432-8). The authors would like to express their gratitude to Embrapa Soja, Rede AgroNano (Embrapa), MCTI/ SisNANO, and DuPont for providing soybean straw and enzyme cocktails, respectively.

\section{References}

[1] M. L. V. Bose and J. G. Martins Filho, "O papel dos resíduos agroindustriais na alimentação de ruminantes," Informe Agropecuário, vol. 10, no. 119, pp. 3-7, 1984.

[2] C. Wan, Y. Zhou, and Y. Li, "Liquid hot water and alkaline pretreatment of soybean straw for improving cellulose digestibility," Bioresource Technology, vol. 102, no. 10, pp. 6254-6259, 2011.

[3] E. Cabrera, M. J. Muñoz, R. Martín, I. Caro, C. Curbelo, and A. B. Díaz, "Comparison of industrially viable pretreatments to enhance soybean straw biodegradability," Bioresource Technology, vol. 194, pp. 1-6, 2015.

[4] L. E. de Ramos e Paula, P. F. Trugilho, A. Napoli, and M. L. Bianchi, "Characterization of residues from plant biomass for use in energy generation," Cerne, vol. 17, no. 2, pp. 237-246, 2011.

[5] X. Z. Tang, P. Kumar, S. Alavi, and K. P. Sandeep, "Recent advances in biopolymers and biopolymer-based nanocomposites for food packaging materials," Critical Reviews in Food Science and Nutrition, vol. 52, no. 5, pp. 426-442, 2012.

[6] H. P. S. Abdul Khalil, A. H. Bhat, and A. F. Ireana Yusra, "Green composites from sustainable cellulose nanofibrils: a review," Carbohydrate Polymers, vol. 87, no. 2, pp. 963-979, 2012.

[7] J.-W. Rhim, H.-M. Park, and C.-S. Ha, "Bio-nanocomposites for food packaging applications," Progress in Polymer Science, vol. 38, no. 10-11, pp. 1629-1652, 2013.

[8] X. Xu, F. Liu, L. Jiang, J. Y. Zhu, D. Haagenson, and D. P. Wiesenborn, "Cellulose nanocrystals vs. cellulose nanofibrils: a comparative study on their microstructures and effects as polymer reinforcing agents," ACS Applied Materials \& Interfaces, vol. 5, no. 8, pp. 2999-3009, 2013.

[9] Y. Chen, C. Liu, P. R. Chang, X. Cao, and D. P. Anderson, "Bionanocomposites based on pea starch and cellulose nanowhiskers hydrolyzed from pea hull fibre: effect of hydrolysis time," Carbohydrate Polymers, vol. 76, no. 4, pp. 607-615, 2009.

[10] X. Cao, Y. Chen, P. R. Chang, A. D. Muir, and G. Falk, "Starchbased nanocomposites reinforced with flax cellulose nanocrystals," Express Polymer Letters, vol. 2, no. 7, pp. 502-510, 2008.

[11] E. D. M. Teixeira, D. Pasquini, A. A. S. Curvelo, E. Corradini, M. N. Belgacem, and A. Dufresne, "Cassava bagasse cellulose nanofibrils reinforced thermoplastic cassava starch," Carbohydrate Polymers, vol. 78, no. 3, pp. 422-431, 2009.

[12] A. Alemdar and M. Sain, "Isolation and characterization of nanofibers from agricultural residues-wheat straw and soy hulls," Bioresource Technology, vol. 99, no. 6, pp. 1664-1671, 2008.

[13] A. Kaushik and M. Singh, "Isolation and characterization of cellulose nanofibrils from wheat straw using steam explosion coupled with high shear homogenization," Carbohydrate Research, vol. 346, no. 1, pp. 76-85, 2011.

[14] J. I. Morán, V. A. Alvarez, V. P. Cyras, and A. Vázquez, "Extraction of cellulose and preparation of nanocellulose from sisal fibers," Cellulose, vol. 15, no. 1, pp. 149-159, 2008.

[15] E. Abraham, B. Deepa, L. A. Pothan et al., "Extraction of nanocellulose fibrils from lignocellulosic fibres: a novel approach," Carbohydrate Polymers, vol. 86, no. 4, pp. 1468-1475, 2011.

[16] M. Pääkko, M. Ankerfors, H. Kosonen et al., "Enzymatic hydrolysis combined with mechanical shearing and high-pressure homogenization for nanoscale cellulose fibrils and strong gels," Biomacromolecules, vol. 8, no. 6, pp. 1934-1941, 2007.

[17] P. Satyamurthy, P. Jain, R. H. Balasubramanya, and N. Vigneshwaran, "Preparation and characterization of cellulose nanowhiskers from cotton fibres by controlled microbial hydrolysis," Carbohydrate Polymers, vol. 83, no. 1, pp. 122-129, 2011.

[18] A. de Campos, A. C. Correa, D. Cannella et al., "Obtaining nanofibers from curauá and sugarcane bagasse fibers using enzymatic hydrolysis followed by sonication," Cellulose, vol. 20, no. 3, pp. 1491-1500, 2013.

[19] H. Tibolla, F. M. Pelissari, and F. C. Menegalli, "Cellulose nanofibers produced from banana peel by chemical and enzymatic treatment," LWT-Food Science and Technology, vol. 59, no. 2, pp. 1311-1318, 2014.

[20] F. Beltramino, M. B. Roncero, T. Vidal, A. L. Torres, and C. Valls, "Increasing yield of nanocrystalline cellulose preparation process by a cellulase pretreatment," Bioresource Technology, vol. 192, pp. 574-581, 2015.

[21] E. Dinand, H. Chanzy, and M. R. Vignon, "Parenchymal cell cellulose from sugar beet pulp: preparation and properties," Cellulose, vol. 3, no. 3, pp. 183-188, 1996.

[22] J. Leitner, B. Hinterstoisser, M. Wastyn, J. Keckes, and W. Gindl, "Sugar beet cellulose nanofibril-reinforced composites," Cellulose, vol. 14, no. 5, pp. 419-425, 2007.

[23] A. Dufresne, D. Dupeyre, and M. R. Vignon, "Cellulose microfibrils from potato tuber cells: processing and characterization of starch-cellulose microfibril composites," Journal of Applied Polymer Science, vol. 76, no. 14, pp. 2080-2092, 2000.

[24] J. Zhao, W. Zhang, X. Zhang, X. Zhang, C. Lu, and Y. Deng, "Extraction of cellulose nanofibrils from dry softwood pulp using high shear homogenization," Carbohydrate Polymers, vol. 97, no. 2, pp. 695-702, 2013.

[25] S. Hiasa, S. Iwamoto, T. Endo, and Y. Edashige, "Isolation of cellulose nanofibrils from mandarin (Citrus unshiu) peel waste," Industrial Crops and Products, vol. 62, pp. 280-285, 2014.

[26] Y. H. Oh, I. Y. Eom, J. C. Joo et al., "Recent advances in development of biomass pretreatment technologies used in biorefinery for the production of bio-based fuels, chemicals and polymers," Korean Journal of Chemical Engineering, vol. 32, no. 10, pp. 1945-1959, 2015.

[27] K. Kafle, C. M. Lee, H. Shin et al., "Effects of delignification on crystalline cellulose in lignocellulose biomass characterized by vibrational sum frequency generation spectroscopy and Xray diffraction," BioEnergy Research, vol. 8, no. 4, pp. 1750-1758, 2015. 
[28] M. M. Andrade-Mahecha, F. M. Pelissari, D. R. Tapia-Blácido, and F. C. Menegalli, "Achira as a source of biodegradable materials: isolation and characterization of nanofibers," Carbohydrate Polymers, vol. 123, pp. 406-415, 2015.

[29] J. X. Sun, X. F. Sun, H. Zhao, and R. C. Sun, "Isolation and characterization of cellulose from sugarcane bagasse," Polymer Degradation and Stability, vol. 84, no. 2, pp. 331-339, 2004.

[30] TAPPI, "Method T19 om-54," TAPPI Standard, TAPPI Test Methods, 1991.

[31] TAPPI, "Method T222 om-88," TAPPI Standard, TAPPI Test Methods, 1999.

[32] C. S. Farinas, M. M. Loyo, A. Baraldo Junior, P. W. Tardioli, V. B. Neto, and S. Couri, "Finding stable cellulase and xylanase: evaluation of the synergistic effect of $\mathrm{pH}$ and temperature," New Biotechnology, vol. 27, no. 6, pp. 810-815, 2010.

[33] C. Florencio, F. M. Cunha, A. C. Badino, and C. S. Farinas, "Validation of a novel sequential cultivation method for the production of enzymatic cocktails from Trichoderma strains," Applied Biochemistry and Biotechnology, vol. 175, no. 3, pp. 13891402, 2015.

[34] T. K. Ghose, "Measurement of cellulase activities," Pure and Applied Chemistry, vol. 59, no. 2, pp. 257-268, 1987.

[35] M. J. Bailey, P. Biely, and K. Poutanen, "Interlaboratory testing of methods for assay of xylanase activity," Journal of Biotechnology, vol. 23, no. 3, pp. 257-270, 1992.

[36] G. L. Miller, "Use of dinitrosalicylic acid reagent for determination of reducing sugar," Analytical Chemistry, vol. 31, no. 3, pp. 426-428, 1959.

[37] L. Segal, J. J. Creely, A. E. Martin, and C. M. Conrad, "An empirical method for estimating the degree of crystallinity of native cellulose using the X-ray diffractometer," Textile Research Journal, vol. 29, no. 10, pp. 786-794, 1959.

[38] P. B. Filson and B. E. Dawson-Andoh, "Sono-chemical preparation of cellulose nanocrystals from lignocellulose derived materials," Bioresource Technology, vol. 100, no. 7, pp. 2259-2264, 2009.

[39] C. J. Chirayil, J. Joy, L. Mathew, M. Mozetic, J. Koetz, and S. Thomas, "Isolation and characterization of cellulose nanofibrils from Helicteres isora plant," Industrial Crops and Products, vol. 59, pp. 27-34, 2014.

[40] W. P. Flauzino Neto, H. A. Silvério, N. O. Dantas, and D. Pasquini, "Extraction and characterization of cellulose nanocrystals from agro-industrial residue-Soy hulls," Industrial Crops and Products, vol. 42, no. 1, pp. 480-488, 2013.

[41] D. Cho, S. Lee, and M. W. Frey, "Characterizing zeta potential of functional nanofibers in a microfluidic device," Journal of Colloid and Interface Science, vol. 372, no. 1, pp. 252-260, 2012.

[42] G. Buschle-Diller, M. K. Inglesby, and Y. Wu, "Physicochemical properties of chemically and enzymatically modified cellulosic surfaces," Colloids and Surfaces A: Physicochemical and Engineering Aspects, vol. 260, no. 1-3, pp. 63-70, 2005.

[43] C. S. Julie Chandra, N. George, and S. K. Narayanankutty, "Isolation and characterization of cellulose nanofibrils from arecanut husk fibre," Carbohydrate Polymers, vol. 142, pp. 158-166, 2016.

[44] K. Kafle, K. Greeson, C. Lee, and S. H. Kim, "Cellulose polymorphs and physical properties of cotton fabrics processed with commercial textile mills for mercerization and liquid ammonia treatments," Textile Research Journal, vol. 84, no. 16, pp. 16921699, 2014.
[45] Y. Yue, J. Han, G. Han, Q. Zhang, A. D. French, and Q. Wu, "Characterization of cellulose I/II hybrid fibers isolated from energycane bagasse during the delignification process: morphology, crystallinity and percentage estimation," Carbohydrate Polymers, vol. 133, pp. 438-447, 2015.

[46] D. J. Silva and M. L. O. D’Almeida, "Nanocristais de celulosecellulose whiskers," Revista O Papel, vol. 70, no. 7, pp. 34-52, 2009.

[47] H. Yang, R. Yan, H. Chen, D. H. Lee, and C. Zheng, "Characteristics of hemicellulose, cellulose and lignin pyrolysis," Fuel, vol. 86, no. 12-13, pp. 1781-1788, 2007.

[48] B. C. Saha, "Hemicellulose bioconversion," Journal of Industrial Microbiology and Biotechnology, vol. 30, no. 5, pp. 279-291, 2003.

[49] M. P. Coughlan, "The properties of fungal and bacterial cellulases with comment on their production and application," Biotechnology and Genetic Engineering Reviews, vol. 3, no. 1, pp. 39-110, 1985.

[50] V. Arantes and J. Saddler, "Access to cellulose limits the efficiency of enzymatic hydrolysis: the role of amorphogenesis," Biotechnology for Biofuels, vol. 3, article 4, 2010. 

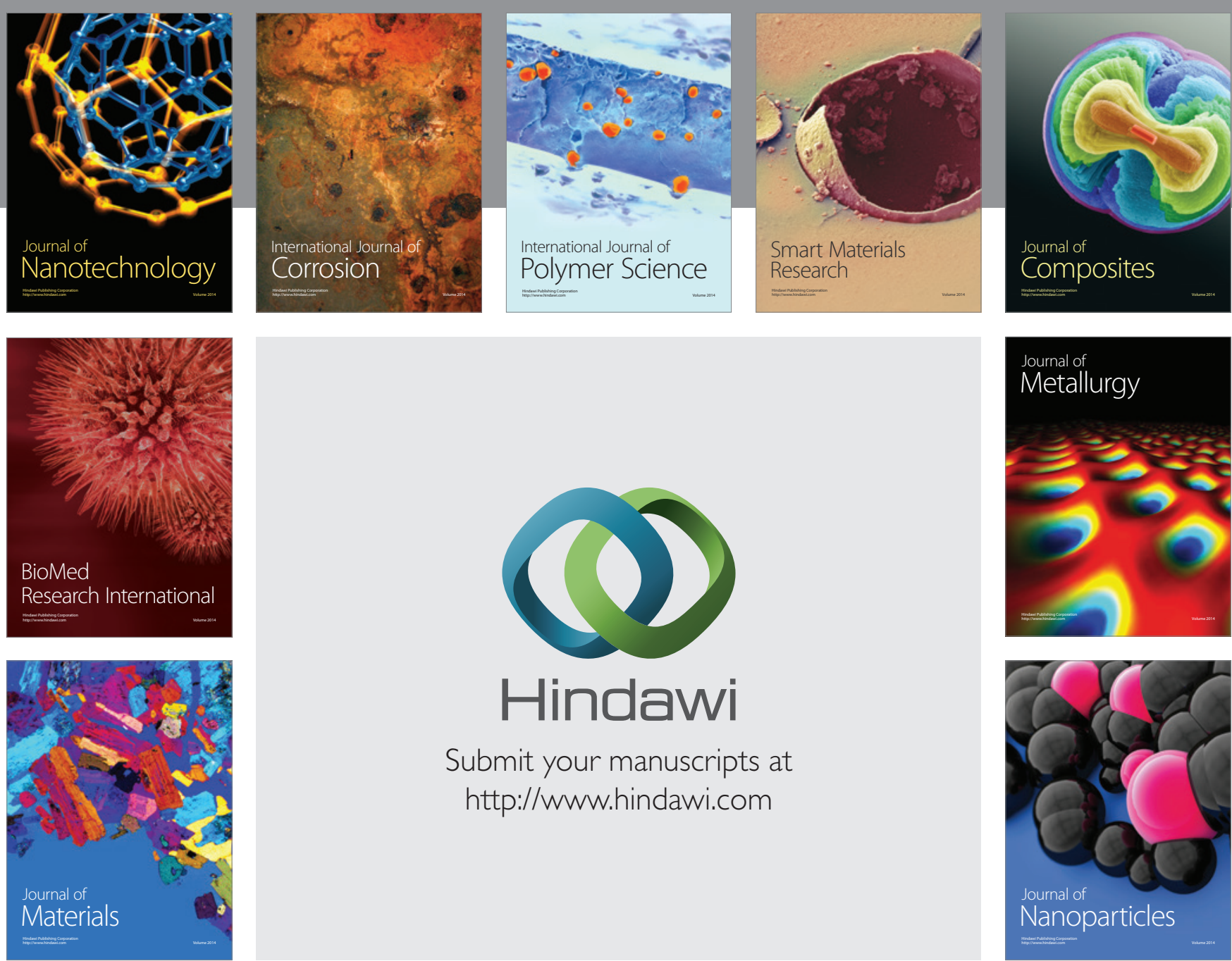

\section{Hindawi}

Submit your manuscripts at

http://www.hindawi.com

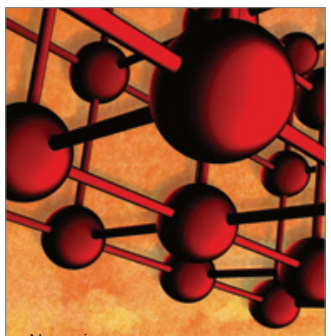

Materials Science and Engineering
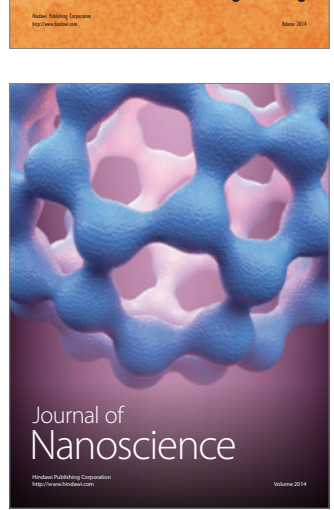
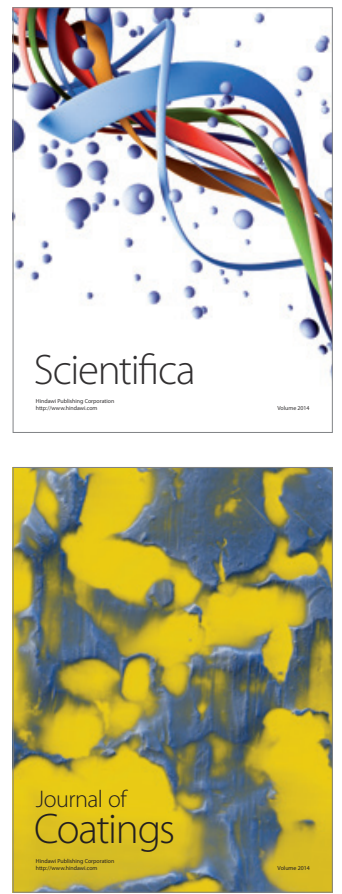
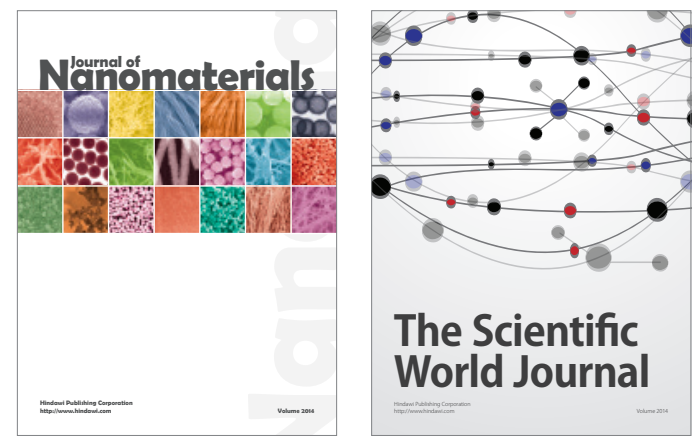

The Scientific World Journal
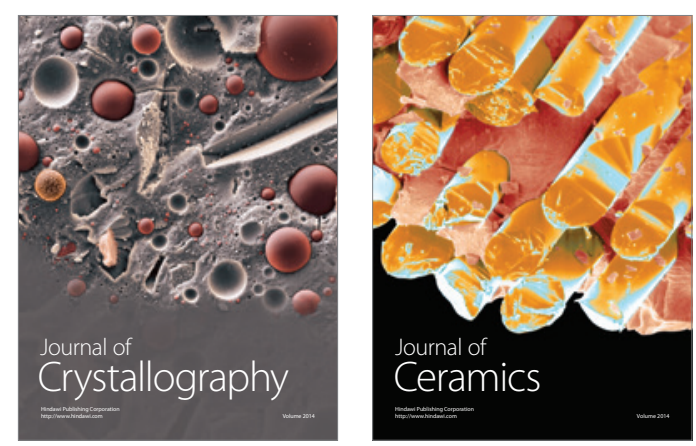
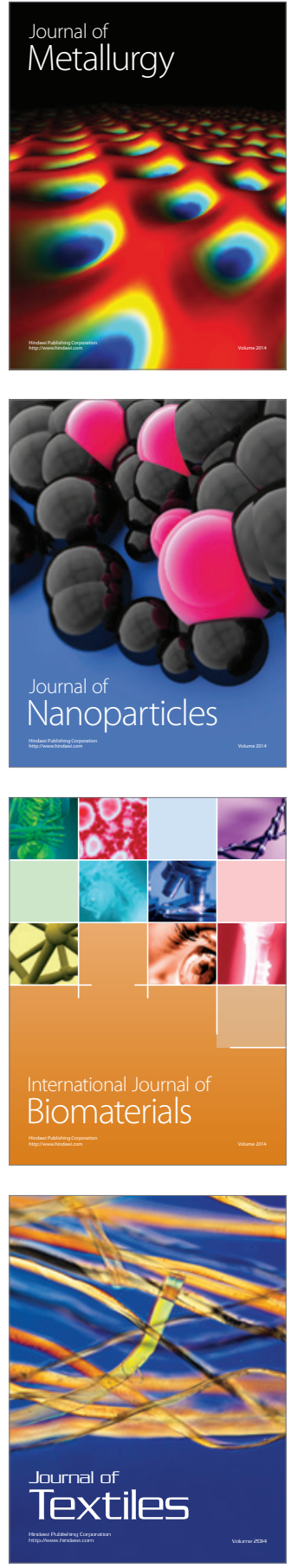